\title{
Chemotaxonomic Significance of Catechin 7-O-beta-D-apiofuranoside in Ulmus Species $^{1}$
}

\author{
Mi $\mathrm{KIM}^{2 *} \cdot$ Yong Jo $\mathrm{LEE}^{3^{*}} \cdot$ Jae-Cheon $\mathrm{SHIN}^{4} \cdot$ Sun Eun $\mathrm{CHOI} \mathbb{C}^{5, \dagger}$
}

\begin{abstract}
Ulmus genus has excellent various physiological activities, including anti-ulcer, antioxidant, antibacterial, anti-cancer, immunity, and homeostasis maintenance effects, and it is known to have many additional drug effects And one of reasons for these excellentbiological activities is a flavan-3-ol chemical group in Ulmus genus. In this study a new flavan-3-ol compound was identified in Ulmus davidiana var. japonica. A flavan-3-ol,(2R,3S)-7-[(2S,3R,4R)-3,4-dihydroxy-4(hydroxymethyl)oxolan-2-yl]oxy-2-(3,4-dihydroxyphenyl)-3,4-dihydro-2H-chromene-3,5-diol, named as catechin 7-O-beta-D apiofuranoside, was isolated from the stems and barks of Ulmus davidiana var japonica for. suberosa, which is a species belonging to the genus Ulmus, growing throughout the Korea peninsula. The structure was elucidated by various spectroscopic methods including high-resolution TOF mass spectrometry, ${ }^{1} \mathrm{H}-\mathrm{NMR}$ and ${ }^{13} \mathrm{C}-\mathrm{NMR}$ spectrometry and comparison with chemical structures of defined compounds.
\end{abstract}

Keywords: Ulmus davidiana var. japonica for. suberosa, flavan-3-ol, chemotaxonomy

\section{INTRODUCTION}

More than 30 species belonging to Ulmus genus grow in temperate regions of the Northern Hemisphere. Six species and two varieties of this genus are found in Korea: U. davidiana Planchon, U. davidiana Planchon var. japonica Nakai, U. laciniata Mayr, U. macrocarpa Hence, U. macrophylla Nakai, U. parvifolia Jacq.(U. coreana Nakai), U. pumila Linne (U. mandshurica Nakai) and Ulmus davidiana var. japonica for. Suberosa (Jung, 1974; Lee, 1996).
Flavan-3-ols are characteristic chemical components of Ulmus species (Son et al., 1989; Moon et al., 1995; Doskotch et al., 1973; Jung et al., 2007). Several interesting biological activities of flavan-3-ols including anti-inflammatory, anti-cancer, analgesic, antimicrobial, antineoplastic, anti-ulcer, antioxidant, antibacterial, anticancer and immunomodulatory properties have been reported previously (Hong et al., 1990; Park et al., 1996; Yang et al., 1996; Cho et al., 1996; Jun et al., 1998; Lee et al., 2000; Lee et al., 2001; Kim et al., 2002).

A flavan-3-ol compound, (+)-catechin 7-O- $\beta$-D-xy-

${ }^{1}$ Date Received September 11, 2020, Date Accepted November 2, 2020

2 Department of Cosmetology Science, Nambu University, Gwangju 62271, Republic of Korea

3 YEONGHWA FEED CO., LTD., \#311, Chosun University Incubator Center, 309, Pilmun-daero, Dong-gu, Gwangju 61452, Republic of Korea

${ }^{4}$ Pohang Center for Evaluation of Biomaterials, 394, Jigok-ro, Nam-gu, Pohang, Gyeongbuk 37668, Republic of Korea

${ }^{5}$ Division of Forest Material Science \& Engineering, College of Forest \& Environmental Sciences, Kangwon National University, Chuncheon 24341, Republic of Korea

* These authors contributed equally to this work.

$\dagger$ Corresponding author: Sun Eun CHOI (e-mail: oregonin@kangwon.ac.kr, ORCID: 0000-0002-6306-0372) 
lopyranoside was isolated from the bark of $U$. Americana (Doskotch et al., 1973). In addition, (+)catechin and $(+)$-catechin 5-O- $\beta$-D-apiofuranoside from roots of $U$. davidiana were isolated (Son et al., 1989). Isoquercetin and rutin from leaves of $U$. parvifolia were isolated (Kim et al., 1992). Sterols, sterol glucoside and (+)-catechin 7-O- $\alpha$-L-rhamnoside from barks of U. parvifolia were isolated (Moon et al., 1995). Sesquiterpene O-naphthoquinone of davidianone A, B, $\mathrm{C}$ and mansonone $\mathrm{E}, \mathrm{F}, \mathrm{H}, \mathrm{I}$ from roots of $U$. davidiana were isolated (Kim et al., 1996). (+)-Catechin7-O- $\beta-D-$ apiofuranoside, lyoniside, 5'-methoxyisolariciresinol-9'O- $\beta$-D-xylopyranoside, rel-trans dihydrodehydroconiferyl alcohol 4-O- $\alpha$-L-rhamnoside, icariside and ulmicine A-E from barks and roots of $U$. davidiana var. japonica were isolated (Bae et al., 2000), respectively.

In this study, we isolated and identified catechin 7-O-beta-D apiofuranoside from the stems and barks of $U$. davidiana var. japonica for. suberosa. We also report the screening of catechin 7-O-beta-D apiofuranoside from other Ulmus species [U. davidiana Planchon (leaves, stems and barks), U. davidiana var. japonica (leaves, stems), U. parvifolia Jacq (stems and barks) and U. pumila Linne (stems)].

\section{MATERIALS and METHODS}

\subsection{Plant extracts of UImus species}

The stems and barks of $U$. davidiana var. japonica for. suberosa (bar code; PB2437.1) as well as $\mathrm{MeOH}$ extracts of $U$. pumila Linne (stems, bar code; PB2430.2), U. parvifolia Jacq (stems and barks, bar code; PB2427.1), U. davidiana var. japonica (stems, leaves, bar code; PB2436.6 7), and U. davidiana Planchon (leaves, stems and barks, bar code; PB2435.1 2) were purchased from the Korea Plant Extract Bank(Cheongju, Korea).

\subsection{Chemical separation and identification}

Thin layer chromatography (TLC) was carried out using a pre-coated silica gel $60 \mathrm{~F}_{254}$ plate (Merck, Darmstadt, Germany) with chloroform, methanol and water (70:30:4, volume ratio). The spots were detected under UV radiation $(254 \mathrm{~nm})$ and by spraying with $\mathrm{FeCl}_{3}$ and $10 \% \mathrm{H}_{2} \mathrm{SO}_{4}$ followed by heating.

The components derived from the Ulmus species were identified by several instrumental analyses. Based on 1D nuclear magnetic resonance (NMR), ${ }^{1} \mathrm{H}-(400 \mathrm{MHz})$ and ${ }^{13} \mathrm{C}-(100 \mathrm{MHz})$ NMR experiments were recorded with FT-NMR Spectrometer $400 \mathrm{MHz}$, AVANCE III HD 400 (Bruker Corporation, Billerica, Massachusetts, USA) at Chonnam National University. Also, a highresolution TOF mass spectrometry was conducted with JMS-T200GC (JEOL, Tokyo, Japan) at the National Center for Inter-University Research Facilities on Chonnam National University.

\subsection{Quantitative analysis of catechin $7-O-\beta-D$ apiofuranoside of UImus species using high pressure liquid chromatography (HPLC)}

HPLC was used for the quantitative analysis of catechin 7-O-beta-D apiofuranoside. A Waters 2695 separation module (Milford, MA, USA) equipped with a vacuum degasser, a binary pump, a 2487 dual $\lambda$ absorbance detector and column compartment, was used to separate 1 on a Phenomenex KJ0-4282 guard column and SkyPakC18 column $(4.6 \times 250 \mathrm{~mm}, 5$ ìm particle) with a linear gradient [D.W. : $\mathrm{MeOH}: \mathrm{P}_{2} \mathrm{HO}_{4}$ $(940: 50: 1)]:\left[\mathrm{MeOH}: \mathrm{P}_{2} \mathrm{HO}_{4}(990: 1)\right]=100: 0$ to $0: 100$ for $30 \mathrm{~min}$. The column temperature was maintained at room temperature. The flow rate was 1.0 $\mathrm{mL} / \mathrm{min}$. The injection volume of each sample was 20 $\mu \mathrm{L}$. The system was monitored at $280 \mathrm{~nm}\left(\lambda_{\max }\right.$ of catechin 7-O-beta-D apiofuranoside) eluting at14.44 \pm $0.14 \mathrm{~min}$, and catechin 7-O- $\beta-\mathrm{D}$ apiofuranoside was 
detected in the extracts of the stems and barks of $U$. davidiana var. japonica for. suberosa, as well as the extracts of $U$. davidiana Planchon (leaves, stems and barks), U. davidiana var. japonica (leaves, stems), $U$. parvifolia Jacq (stems and barks) and U. pumila Linne (stems).

\section{RESULTS and DISCUSSION}

Brown amorphous powder, high-resolution TOF MS m/z: $422.17511[\mathrm{M}]^{+} ;{ }^{1} \mathrm{H}-\mathrm{NMR}$ (400 MHz, DMSO- $d_{6}$ $\left.+\mathrm{D}_{2} \mathrm{O}\right): 6.74(\mathrm{H}-2$ ', 1H, d, J = 2.0 Hz), $6.69(\mathrm{H}-5$ ', $1 \mathrm{H}$, d, J = $8.4 \mathrm{~Hz}), 6.59(\mathrm{H}-6,1 \mathrm{H}, \mathrm{dd} \mathrm{J}=2.0,8.4 \mathrm{~Hz})$, $6.09(\mathrm{H}-8,1 \mathrm{H}, \mathrm{d}, \mathrm{J}=2.4 \mathrm{~Hz}), 5.90(\mathrm{H}-6,1 \mathrm{H}, \mathrm{J}=2.4$ $\mathrm{Hz}), 5.33(\mathrm{H}-1$ ”, $1 \mathrm{H}, \mathrm{d}, \mathrm{J}=4.0 \mathrm{~Hz}), 4.55(\mathrm{H}-2,1 \mathrm{H}, \mathrm{d}$, $\mathrm{J}=7.2 \mathrm{~Hz}), 4.03(\mathrm{H}-2 ", 1 \mathrm{H}, \mathrm{d}, \mathrm{J}=4.0 \mathrm{~Hz}), 4.00(\mathrm{H}-4 \mathrm{a}$ ", $1 \mathrm{H}, \mathrm{d}, \mathrm{J}=9.6 \mathrm{~Hz}), 3.89(\mathrm{H}-3,1 \mathrm{H}, \mathrm{m}), 3.68(\mathrm{H}-4 \mathrm{~b} ", 1 \mathrm{H}$, d, J = 9.6 Hz), $3.45(\mathrm{H}-5$ ”, 2H, m), $2.65(\mathrm{H}-4 \mathrm{a}, 1 \mathrm{H}$, $\mathrm{dd}, \mathrm{J}=4.8,16.0 \mathrm{~Hz}), 2.40(\mathrm{H}-4 \mathrm{~b}, 1 \mathrm{H}, \mathrm{dd}, \mathrm{J}=8.0,16.0 \mathrm{z})$; ${ }^{13} \mathrm{C}-\mathrm{NMR}\left(100 \mathrm{MHz}\right.$, DMSO- $\left.d_{6}+\mathrm{D}_{2} \mathrm{O}\right): \delta 156.7(\mathrm{C}-7)$, 156.5 (C-5), 155.7 (C-9), 145.2 (C-4'), 145.1 (C-3'), 130.8 (C-1'), 118.8 (C-6'), 115.6 (C-5'), 114.7 (C-2'), 107.3 (C-1"), 102.1 (C-10), 96.0 (C-8), 95.3 (C-6), 81.4 (C-2), 78.9 (C-3"), 76.3 (C-2”), 74.3 (C-4”), 66.3 (C-3), 62.4 (C-5"), 27.8 (C-4).

Compound catechin 7-O-beta-D apiofuranoside was brown amorphous powder. The spot was detected under UV radiation at $254 \mathrm{~nm}$, the black spot was detected by spraying with $\mathrm{FeCl}_{3}$ and dark brown and orange spots was detected by spraying $10 \% \mathrm{H}_{2} \mathrm{SO}_{4}$ and anisaldehyde- $\mathrm{H}_{2} \mathrm{SO}_{4}$ followed by heating, respectively.

An aromatic $\mathrm{ABX}$-spin system, the presence of meta-coupled aromatic signal $[\delta 6.74(1 \mathrm{H}, \mathrm{d}, J=2.0 \mathrm{~Hz}$, $\left.\left.\mathrm{H}-2^{\prime}\right)\right]$, ortho-coupled aromatic signal $[\delta 6.69(1 \mathrm{H}, \mathrm{d}$, $\left.\left.J=8.4 \mathrm{~Hz}, \mathrm{H}-5^{\prime}\right)\right]$ and ortho-meta-coupled aromatic signal $\left[\delta 6.59\left(1 \mathrm{H}, \mathrm{dd}, J=2.0,8.4 \mathrm{~Hz}, \mathrm{H}-6^{\prime}\right)\right]$ was showed in ${ }^{1} \mathrm{H}-\mathrm{NMR}$ spectrum. The two carbon signals of C-3' and 4' were observed in downfield ( $\delta$ 145.1, 145.2) compared with the peaks of C-2', 5' and 6' $(\delta$
114.7, 115.6 and 118.8) in ${ }^{13} \mathrm{C}-\mathrm{NMR}$ spectrum. These meant B-ring was pyrocatechol moiety which was substituted by hydroxyl group in C-3' and 4'. The signals of two more aromatic protons, which were meta-coupled ones [ $\delta 5.90(1 \mathrm{H}, \mathrm{d}, J=2.4 \mathrm{~Hz}, \mathrm{H}-6), \delta 6.09(1 \mathrm{H}$, $\mathrm{d}, J=2.4 \mathrm{~Hz}, \mathrm{H}-8)]$ were observed in ${ }^{1} \mathrm{H}-\mathrm{NMR}$ spectrum, and the three carbon signals of $\mathrm{C}-5, \mathrm{C}-7$ and C-9, $(\delta 155.7,156.5$ and 156.7) were deshielded rather than C-6, 8 and 10 ( $\delta 95.3,96.0$ and 102.1) in ${ }^{13} \mathrm{C}-\mathrm{NMR}$ spectrum.

These implied A-ring was related to phloroglucinol moiety which was substituted by hydroxyl group in C-5, 7 and 9. However the five carbon signals of 62.4 (api-5), 74.3 (api-4), 76.3 (api-2), 78.9 (api-3), 107.3 (api-1) indicate sugar existence in ${ }^{13} \mathrm{C}-\mathrm{NMR}$ spectrum. These signals were indicative of a $\mathrm{D}$-apiofuranoside (Shengjun et al., 2000). The linkage of this sugar at C-7 was established by comparing the spectral data with the values reported in the literature $(\mathrm{Na}$ et al., 2002). Moreover, the proton signals of $\mathrm{H}-2$ [ $\delta 4.55$ $(1 \mathrm{H}, \mathrm{d}, J=7.2 \mathrm{~Hz})], \mathrm{H}-3\left[\delta 3.89(1 \mathrm{H}, \mathrm{m}), \mathrm{H}-4_{\text {eq }}[\delta 2.65\right.$ $(1 \mathrm{H}, \mathrm{dd}, J=4.8,16.0 \mathrm{~Hz})]$ and $\mathrm{H}-4_{\text {ax }}[\delta 2.40(1 \mathrm{H}, \mathrm{dd}$, $J=8.0,16.0 \mathrm{~Hz})]$ were observed in ${ }^{1} \mathrm{H}-\mathrm{NMR}$ and the carbon signals in ${ }^{13} \mathrm{C}-\mathrm{NMR}$ spectrum of $\mathrm{C}-2,3$ and $4(\delta 81.4,66.3$ and 27.8) indicated flavan-3ol moiety. Especially, the large coupling constant of $\mathrm{H}-2(J=7.2$ $\mathrm{Hz})$ in ${ }^{1} \mathrm{H}-\mathrm{NMR}$ and carbon signals of $\mathrm{C}-2$ at $\delta 81.4$ in ${ }^{13} \mathrm{C}$-NMR suggested a 2,3-trans-configuration.

Thus, compound 1 was identified as catechin 7-O- $\beta$ -D apiofuranoside based on the spectral data compared with the valuesreported in the previous studies (Jung et al., 2007; Bae et al., 2000; Shengjun et al., 2000; $\mathrm{Na}$ et al., 2002).

We quantified catechin 7-O-beta-D apiofuranoside from the stem and bark extracts of $U$. davidiana var. japonica for. Suberosa $[172.35 \pm 0.158 \mathrm{ppm}(\mu \mathrm{g} / \mathrm{mL})$, $17.24 \pm 0.016 \%$ ] (Fig. 3), the leaf extracts of $U . d a-$ vidiana Planchon $[191.38 \pm 0.219 \mathrm{ppm}(\mu \mathrm{g} / \mathrm{mL}), 19.14$ $\pm 0.022 \%$ ] (Fig. 4), the stem and bark extracts of $U$. 
davidiana Planchon $[177.84 \pm 0.209 \mathrm{ppm}(\mu \mathrm{g} / \mathrm{mL})$, $17.78 \pm 0.021 \%$ ] (Fig. 5), the leaf extract of $U . d a-$ vidiana var. japonica $[176.11 \pm 0.155 \mathrm{ppm}(\mu \mathrm{g} / \mathrm{mL})$, $17.61 \pm 0.015 \%]$ (Fig. 6), the stem extract of $U . d a-$ vidiana var. japonica $[41.27 \pm 0.191 \mathrm{ppm}(\mu \mathrm{g} / \mathrm{mL})$, $4.13 \pm 0.019 \%$ ] (Fig. 7), the stem and bark extracts of U. parvifolia Jacq $[150.88 \pm 0.205 \mathrm{ppm}(\mu \mathrm{g} / \mathrm{mL})$, $15.09 \pm 0.020 \%]$ (Fig. 8) and the stem extract of $U$. pumila Linne $[61.69 \pm 0.178 \mathrm{ppm}(\mu \mathrm{g} / \mathrm{mL}), 6.17 \pm$ $0.018 \%$ ] (Fig. 9), using a calibration equation $(\mathrm{y}=$ $\left.6857.3 \mathrm{x}-42331 ; \mathrm{R}^{2}=0.9985\right)$. According to the results of the content analysis experiment using HPLC, there was no significant difference in the content of the indicator substance in the other samples except for the two samples (the stem extract of $U$. davidiana var.

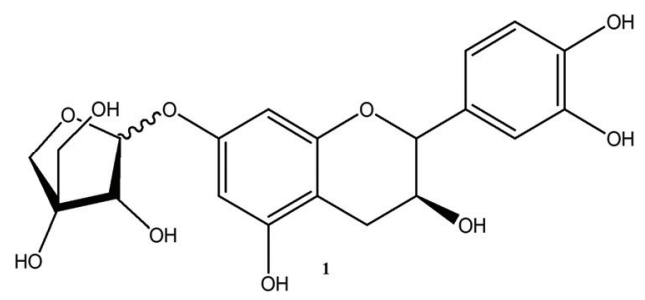

Fig. 1. Chemical structures of compound 1 isolated from Ulmus species.

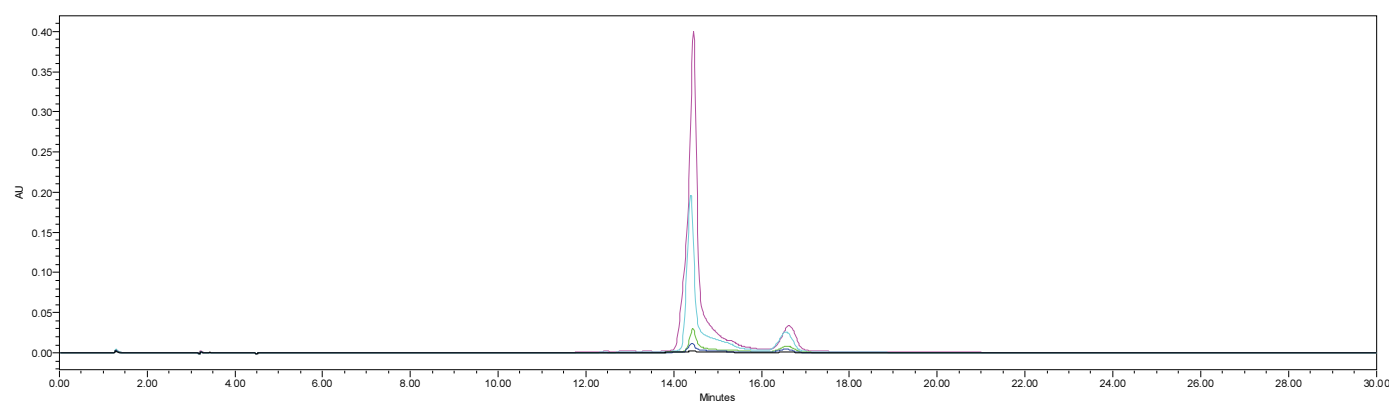

Fig. 2. HPLC chromatogram of compound 1. Sample $1=$ Com. 1 1,000ppm(purple color line), Sample $2=$ Com. 1500 ppm (mint color line), Sample 3 = Com. 1100 ppm (green color line), Sample $4=$ Com. 150 ppm(blue color line).

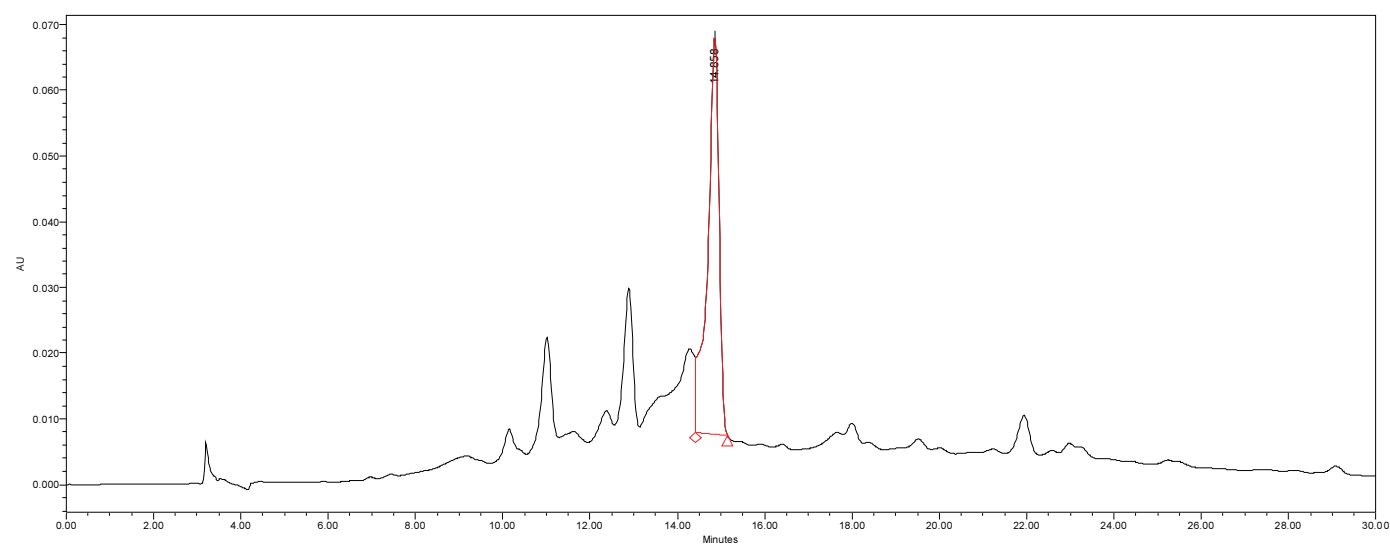

Fig. 3. HPLC chromatogram of the stem and bark extracts of $U$. davidiana var. japonica for. suberosa. Sample $1=$ stem and bark extracts of $U$. davidiana var. japonica for. suberosa. 1,000 ppm. 


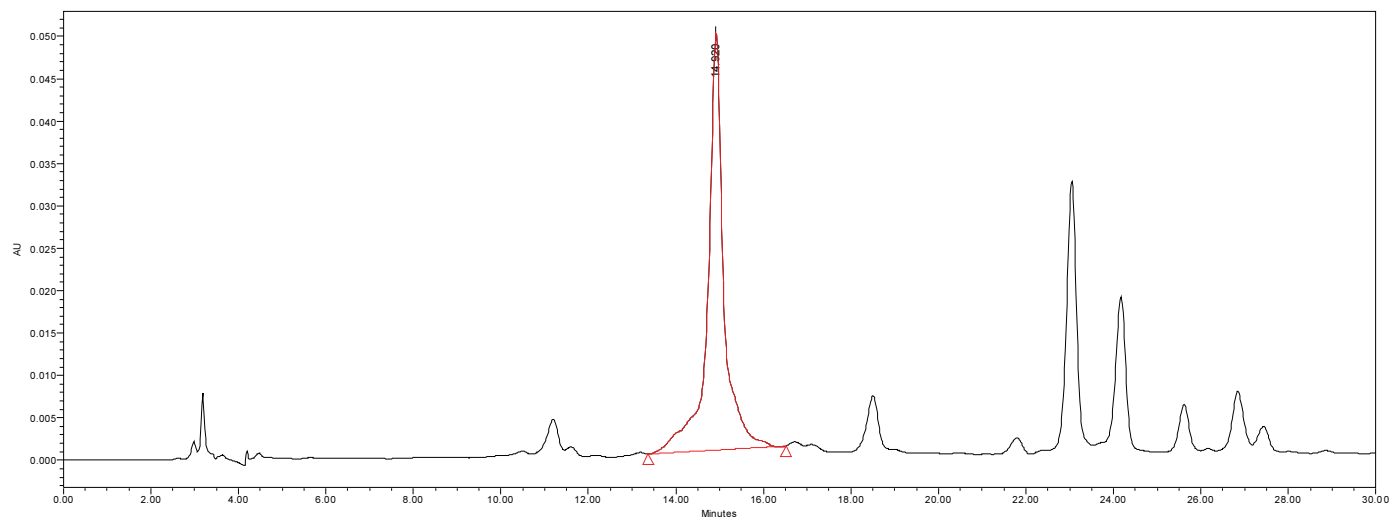

Fig. 4. HPLC chromatogram of the leaf extract of $U$. davidiana Planchon. Sample $1=$ leaf extract of U. davidiana Planchon.1,000 ppm.

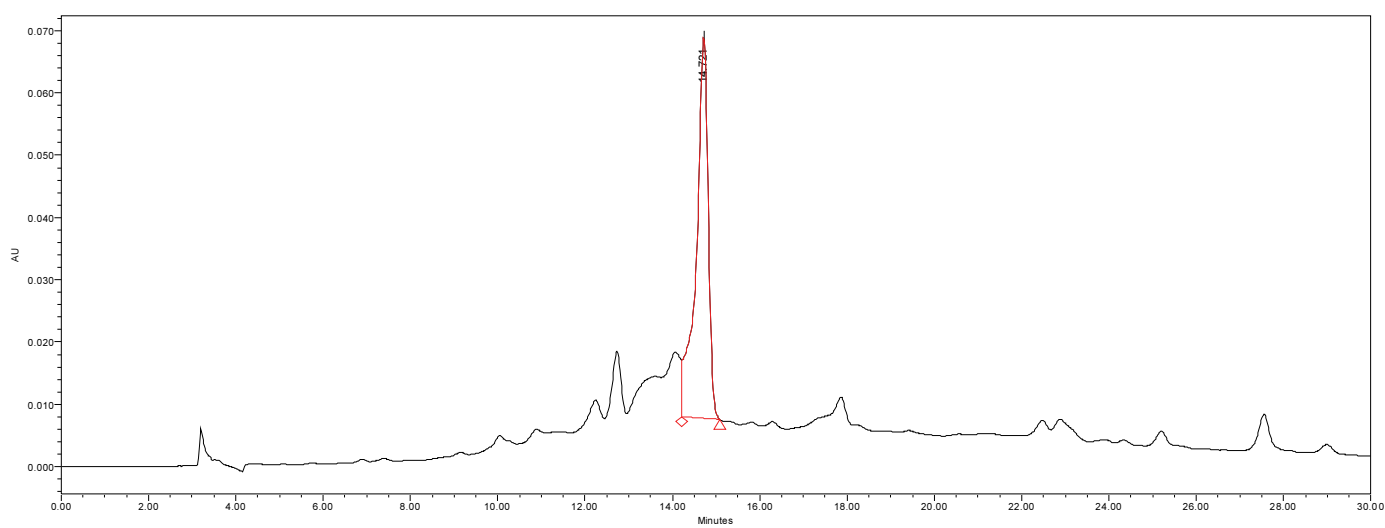

Fig. 5. HPLC chromatogram of the stem and bark extracts of $U$. davidiana Planchon. Sample $1=$ stems and bark extract of $U$. davidiana Planchon.1,000 ppm.

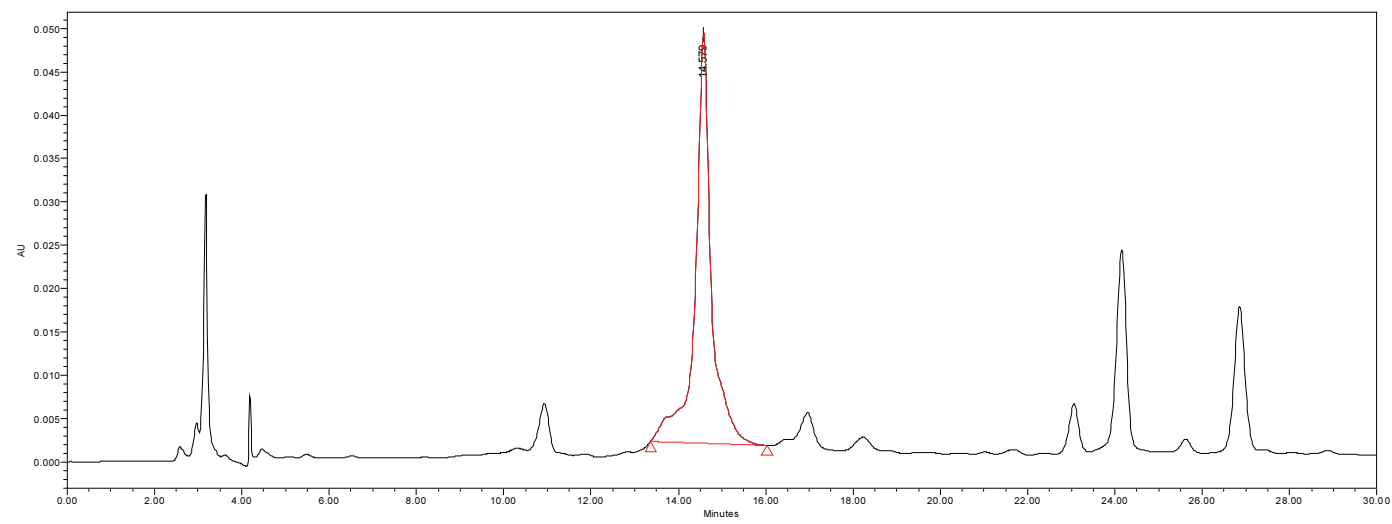

Fig. 6. HPLC chromatogram of the leaf extract of $U$. davidiana var. japonica. Sample $1=$ leaf extract of $U$. davidiana var. japonica.1,000 ppm. 


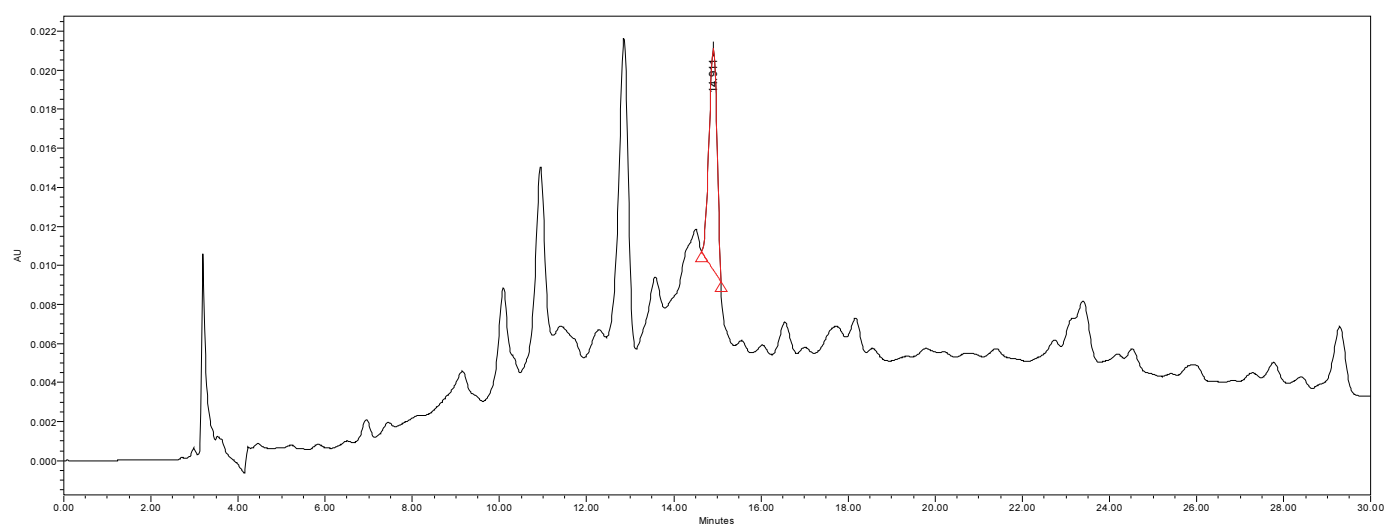

Fig. 7. HPLC chromatogram of the stem extract of $U$. davidiana var. japonica. Sample $1=$ stem extract of $U$. davidiana var. japonica. $1,000 \mathrm{ppm}$.

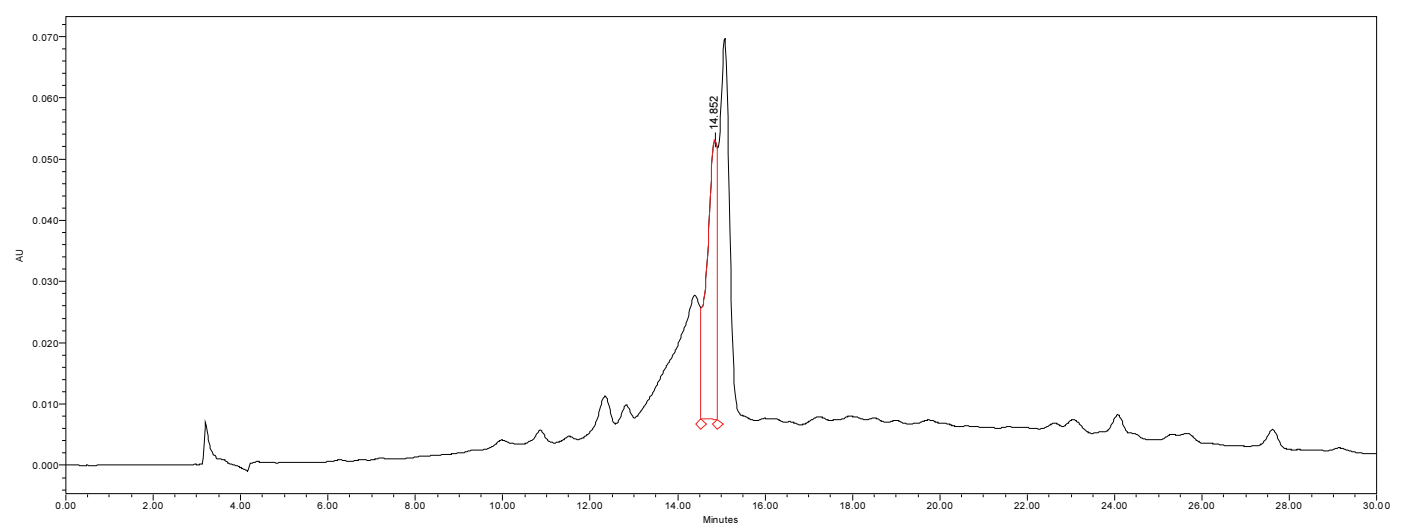

Fig. 8. HPLC chromatogram of the stem and bark extracts of $U$. parvifolia Jacq. Sample $1=$ stems and bark extract of U. parvifolia Jacq.1,000 ppm.

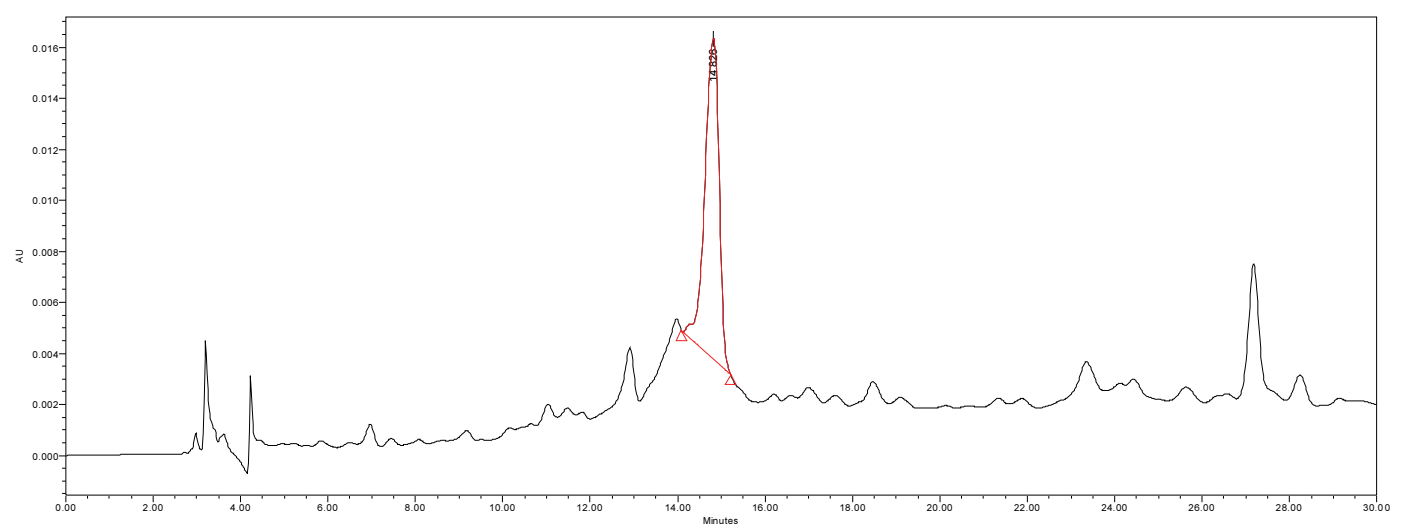

Fig. 9. HPLC chromatogram of the stem extract of $U$. pumila Linne. Sample $1=$ stem extract of $U$. pumila Linne. 1,000 ppm. 
japonica and the stem extract of U. pumila Linne), but the two samples with a significantly lower level were important experimental results when evaluating the value of future use of raw materials. It is expected to be used as important basic data in future resource utilization.

\section{CONCLUSION}

This is the first report of the isolation and identification of catechin 7-O-beta-D apiofuranosidefrom $U$. davidiana var. japonica for. suberosa., U. parvifolia Jacq and U. davidiana Planchon. Since the initial isolation of catechin 7-O-beta-D apiofuranoside from $U$. Americana (Doskotch et al., 1973), it has been found to be distributed among $U$. davidiana var. japonica (Jung et al., 2007) and U. macrocarpa Hance (Kwon et al., 2011).

Based on the above results, it is expected that it will be used as an important research result in searching for new natural materials that can be given high added value.

\section{ACKNOWLEDGMENT}

This study was supported by the ' $R \& D$ Program for Forest Science Technology (Project No. 201703 1B10-1819-BA01)' offered by Korea Forest Service (Korea Forestry Promotion Institute), and this study was supported (in part) by 2020 Research Grant from Kangwon National University.

\section{REFERENCES}

Bae, Y.S., Kim, J.K. 2000. Extractives of the bark of ash and elm as medicinal hardwood tree species. Journal of the Korean Wood Science and Technology 28(3): 62-69.

Cho, S.K., Lee, S.G., Kim, C.J. 1996. Anti-inflammatory and analgesic activities of water extract of root bark of Ulmus parvifolia. Korean Journal of Pharmacognosy 27(3): 274-281.

Doskotch, R.W., Milhail, A.A., Chatterji, S.K. 1973. Structure of the water-soluble feeding stimulant for Scolytus multistriatus: A revision. Phytochemistry 12(5): 1153-1155.

Hong, N.D., Rho, Y.S., Kim, N.J., Kim, J.S. 1990. A Study on efficacy of Ulmi cortex. Korean Journal of Pharmacognosy 21(3): 217-222.

Jun, C.D., Pae, H.O., Kim, Y.C., Jeong, S.J., Yoo, J.C., Lee, E.J., Choi, B.M., Chae, S.W., Park, R.K., Chung, H.T. 1998. Inhibition of nitric oxide synthesis by butanol fraction of the methanol extract of Ulmus davidiana in murine macrophages. Journal of Ethnopharmacology 62(2): 129-135.

Jung, T.H. 1974. Korean Flora. Seoul: I-Mun Pubishing Co., Ltd.

Jung, M.J., Heo, S.I., Wang, M.H. 2007. Reducing power and $\alpha$-glucosidase inhibitory profiles of (-)-catechin and its glycoside. Korean Journal of Pharmacognosy 38(4): 358-362.

Kim, S.H., Hwang, K.T., Park, J.C. 1992. Isolation of flavonoids and determination of rutin from the leaves of Ulmus parvifolia. Korean Journal of Pharmacognosy 23(4): 229-234.

Kim, J.P., Kim, W.G., Koshino, H., Jung, J., Yoo, I.D. 1996. Sesquiterpene O-naphthoquinones from the root bark of Ulmus davidiana. Phytochemistry 43(2): 425-430.

Kim, C.S., Lee, J.M., Choi, C.O., Park, S.B., Eom, T.J. 2002. Chemical analysis and isolation of antibacterial compound from Ulmus species (1): chemical analysis and antibacterial activity of extractives. Journal of the Korean Wood Science and Technology 30(4): 66-73.

Kwon, J.H., Kim, S.B., Park, K.H., Lee, M.W. 2011. Antioxidative and anti-inflammatory effects of phenolic compounds from the roots of Ulmus 
macrocarpa. Archives of Pharmacal Research. 34(9): 1459-1466.

Lee, Y.N. 1996. Flora of Korea. Seoul: Kyo-Hak Pubishing Co., Ltd.

Lee, Y.J., Han, J.P. 2000. Antioxidant activities and nitrite scavenging abilities of extracts from Ulmus devidianan. Journal of the Korean Society of Food Science and Nutrition 29(5): 893-899.

Lee, G.H., Shim, C.J., Chang, Y.I., Seong, H., Oh, H.R., Oh, M.J. 2001. Research Papers: Antimicrobial activities of ( - ) epicatechin from Ulmus davidiana var. japonica cortex. Journal of Food Science and Nutrition 6(4): 230-234.

Moon, Y.H., Rim, G.R. 1995. Studies on the constituents of Ulmus parvifolia. Korean Journal of Pharmacognosy 26(1): 1-7.

Na, M.K., An, R.B., Lee, S.M., Min, B.S., Kim, Y.H., Bae, K.H., Kang, S.S. 2002. Antioxidant compounds from the stem bark of Sorbus commixta. Natural
Product Sciences 8(1): 26-29.

Park, S.H., Goo, Y.M., Na, D.S. 1996. Isolation and structure elucidation of a catechin glycoside with phospholipase A2 inhibiting activity from Ulmi cortex. Bulletin of the Korean Chemical Society 17(2): 101-103.

Shengjun, G., Elisabet, F., Lennart, K., Bengt, R., BO, G.S. 2000. Triterpenoid saponins containing an acetylated branched D-fucosyl residue from Quillaja saponaria Molina. Phytochemistry 53(8): 861-868.

Son, B.W., Park, J.H., Zee, O.P. 1989. Catechin glycoside from Ulmus davidiana. Archives of Pharmacal Research 12(3): 219-222.

Yang, Y., Hyun, J.W., Lim, K.H., Kim, H.J., Woo, E.R., Park, J. 1996. Antineoplastic effect of extracts from traditional medicinal plants and various plants (III) Korean Journal of Pharmacognosy 27(2): 105-110. 